\title{
POPULAR PIETY IN INDONESIA: “AESTHETICIZATION” AND REPRODUCTION OF ISLAM*
}

\author{
Muhammad Wildan \\ Witriani \\ The State Islamic University Sunan \\ Kalijaga Yogyakarta, Yogyakarta- \\ Indonesia \\ muhammad.wildan@uin-suka.ac.id \\ https://orcid.org/0000-0003-2111-3891 \\ \& The State Islamic University Sunan \\ Kalijaga Yogyakarta, Yogyakarta- \\ Indonesia \\ witriani@uin-suka.ac.id \\ https://orcid.org/0000-0002-8350-5068
}

\begin{abstract}
Globalization and democratization have greatly contributed to the rise of Islamic popular culture especially popular piety in Indonesia. Popular piety can be defined as Muslims' religious expressions that are driven mostly by their culture or atmosphere rather than their ideology. This article will observe several phenomena of popular piety such as the flourish of the hijâb among middle-class urbanite Muslims, dahwahtainment, the hijrah movement, the burgeoning of 'umrah pilgrimage with celebrities etc. It is interesting to see these phenomena as part of the process of re-Islamization, secularization, or even postIslamism. In my view, popular piety is part of the process of public
\end{abstract}

* The earlier version of this article has been presented at "Trans-L Encounters" Conference at Center for Near Middle-eastern Studies (CNMS) Philipps-University Marburg, Germany on 26-28 May 2016. Many thanks for the comments and kind help of Prof. Albrecht Fuess, Prof. Claudia Derichs, and Prof. Edith Franke.

Ilahiyat Studies

p-ISSN: 1309-1786 / e-ISSN: 1309-1719

Volume 12 Number 2 Summer / Fall 2021

DOI: $10.12730 / 13091719.2021 .122 .227$

Received: September 29, 2021 | Accepted: December 20, 2021 | Published: December 31, 2021.

To cite this article: Wildan, Muhammad, Witriani. "Popular Piety in Indonesia: "Aestheticization" and Reproduction of Islam." Ilabiyat Studies 12, no. 2 (2021): 213-236. https://doi.org/10.12730/13091719.2021.122.227

This work is licensed under Creative Commons Attribution-NonCommercialNoDerivatives 4.O International. 
Islam which in turn will generate civil Islam. The phenomena of popular piety will not only be viewed from the perspective of commodification of Islam and consumerism of Muslims, but also as an "aestheticization" of Islam which would foster a much broader interpretation of Islam in Indonesia.

Key Words: Popular piety, hijāb, 'umrah, public Islam, civil Islam, post-Islamism

\section{Introduction}

As the world's largest populous Muslim country, Indonesian Islam is undergoing such remarkable developments in the last two decades especially since Islam is more publicly visible and articulate. ${ }^{1}$ "Modernization" ${ }^{2}$ and globalization, among the others, have flourished the development of Islam which many scholars name it as Islamic resurgence (Islamization) which is conspicuous almost in all aspects of society. ${ }^{3}$ Currently, Indonesian Muslims which comprise approximately $87 \%$ of the population ${ }^{4}$ have demonstrated their vitality as a system of symbolic and collective identity which in turn has also influenced the social and political dynamics of Indonesian society. Therefore, the positive responses and expressions of Muslims to "modernity" bring Lapidus to assert that Islam is a religion of

1 Robert W. Hefner, Civil Islam, Muslims and Democratization in Indonesia (Princeton: Princeton University Press, 2000), 123.; Azyumardi Azra, "Political Islam in post-Soeharto Indonesia," in Virginia Hooker and Amin Saikal (eds.), Islamic Perspectives on the New Millennium (Singapore: ISEAS, 2004), 133.

2 Regardless of many debates on the discourse of modernization, the writer shares his views with those who believe that there are multiple modernities, to distinguish between modernity in the Western context and other contexts. Further see S. N. Eisenstadt, "Multiple Modernities," Daedalus 129, no. 1, (2000), 1-29.

3 Noorhaidi Hasan, "The Making of Public Islam: Piety, Agency, and Commodification on the Landscape of the Indonesian Public Sphere," Contemporary Islam 3/3 (2009), 232-233, https://doi.org/10.1007/s11562-0090096-9.

4 Based on national census in 2010. Further see Indonesian Central Bureau of Statistics https://sp2010.bps.go.id/index.php/site/tabel?tid=321\&wid=0 (accessed on July 15, 2019). 
modernization. ${ }^{5}$ Along with the rise of Indonesian Muslims' consciousness to demonstrate their religiosity in the public sphere, Islam has increasingly moved to the center and become part of political expressions, legal transactions, economic activities, as well as social and cultural practices. ${ }^{6}$

The rise of Islamic identity in the Indonesian public spheres has been marked by the proliferation of religious symbols and new lifestyles. Currently, many expressions on Islam are more visible in the public spheres and also in the media such as fancy mosques, Islamic schools, Islamic banks, Islamic hospitals and medication, Islamic music and movies, hijāb, $\mathrm{da}^{\mathrm{c}} \mathrm{w}$ ahtainment ${ }^{\top}$ on TV and internet, etc. New genres of $\mathrm{da}^{\mathrm{c}}$ wah such as cyber $\mathrm{da}^{\mathrm{c}}$ wah and cellular da' wah through many kinds of social media and web-based services bring Islam into everyday life and personal convenience, accessibility, and immediacy. ${ }^{8}$ The emergence of Islam in the public spheres is such an expression of Muslims' freedom to express their identity. Undoubtedly, the proliferation of Islamic popular culture is more obvious nowadays due largely to globalization and democratization.

Among the above Islamic popular culture, the writer is particularly interested in the phenomenon of popular piety. Normatively, religiosity is more profound in Islam as personal piety. The flourish of Islam socially and culturally nowadays, however, could be clearly seen as popular piety or symbolic piety. The writer prefers to define the term as the collective forms of religious-based lifestyles practiced by Muslims that are mostly inspired by their circumstances rather than

5 Ira M. Lapidus, "Islamic Revival and Modernity: The Contemporary Movements and the Historical Paradigms," Journal of the Economic and Social History of the Orient 40, no. 4 (1997), 457.

6 Noorhaidi Hasan, Laskar Jihad: Islam, Militancy, and the Quest for Identity in Post-new Order Indonesia (Ithaca: Cornell Southeast Asia Program, 2006).

7 Type of television program of preaching which combine performative religious skills with entertainment, for further reading see Dicky Sofjan "Gender Construction in Dakwahtainment: A Case Study of Hati ke Hati Bersama Mamah Dedeh," Al-Jāmicab: Journal of Islamic Studies 50, 1 (2012), https://doi.org/10.14421/ajis.2012.501.57-74.

8 Greg Fealy, "Consuming Islam: Commodified Religion and Aspirational Pietism in Contemporary Indonesia," in Expressing Islam: Religious Life and Politics in Indonesia, ed. Greg Fealy and Sally White (Singapore: ISEAS, 2008), 29-30, https://doi.org/10.1355/9789812308528-006. 
beliefs. Among this kind of popular culture are the increasing usages of hijāb among urban middle-class Muslims, hijrah ${ }^{9}$ movement and Arabism, ${ }^{10}$ dakwahtainment, etc.

This paper tries to answer some questions such as what are the varieties of popular piety, to what extent do globalization and democracy give to the rise of popular piety, and what is the meaning of popular piety in the dynamics of Islam and modernity in Indonesia. To acquire a good interpretation from the above phenomena, the writer should not rely on the individual context but more important should be within a given social context. Hijāb of female Muslims for example should not only be understood as personal piety (ethical) but could also be viewed as aesthetical or even political phenomena. Likewise, the phenomenon of hijrah among the youth, and the Arabic culture both in fashion and utterances or communication have been seen as a new face of Indonesian Islam. In general, however, popular piety as a phenomenon of democratization of Indonesia could be viewed as aestheticization, reproduction of Islam, moderate Islam, and later exclusivity of Islam.

\section{Public Islam \& Popular Culture}

Since the last decade of the New Order government in the 1990s, Islam has been flourishing significantly in Indonesia. The government's openness towards Muslims provided an opportunity for the emergence of the middle-class Muslim generation to exhibit religious symbols more explicitly in the public sphere. ${ }^{11}$ Owing to the mass and rapid development of Islamic education since the mid of the New Order government, devout Muslims (santri) rose significantly and

9 Historically, the term hijrah is traced to the commemoration of the day when the Prophet Muhammad (PBUH) emigrated from Makkah to Madinah. The term is translated as emigration especially among young generation of Muslims to declare a spiritual emigration and pursue a better life in the world and here after. For further reading see Taufiqur Rahman et al. "Hijrah and the Articulation of Islamic Identity of Indonesian Millenials on Instagram," Jurnal Komunikasi: Malaysian Journal of Communication 37/2 (2021), 154-170.

10 The term is related to the adoption of Arabic cultures such as lifestyle, language, fashion as the Muslim daily life.

11 Fealy, "Consuming Islam," 15-16. 
became a significant segment in the society. ${ }^{12}$ Witnessing the shift of the attitude of the state towards Islam, Indonesian Muslims initiated various activities to demonstrate the victory of Islam. Since they believe that Islam could play a significant role in the public arena, they implemented various "Islamic visions" at the level of education, economics, as well as politics.

Furthermore, Brenner argues that since the late 1970s the phenomenon of 'the Islamic resurgence' has had a profound impact on religion, politics, and society throughout the Islamic world and beyond. As she further explains:

One of the most conspicuous symbols of this powerful and resilient movement is the style of women's clothing or 'veil.' In Java veiling isymbolizes a new historical consciousness that deliberately disassociates itself from the past. Javanese women who adopt the veil often invoke the idiom of 'becoming aware' as a means of distancing themselves from their own pasts and conceptualizing the process by which they have used their newfound knowledge and practice of Islam to bring about the personal change. ${ }^{13}$

In addition, the development of Islam in the country is also reinforced by global Islam which also reverberated since the end of the $20^{\text {th }}$ century. Undeniably, however, although global Islam also brought about a significant influence on Islamism or even radicalism, the writer believes that moderate Islam would be much obvious in the religious life in Indonesia. Globalization also brings about the influx of foreign culture in the country which in turn influenced significantly Indonesian culture including the Islamic popular culture. Eventually, popular Islam is one of the phenomena of the emergence of public Islam.

When religion comes to a certain territory, it undergoes such kind of contextualization since religion is such a culture that could be also adaptive to certain social settings and corresponds to surrounding

12 Farish A. Noor, "Popular Religiosity in Indonesia Today: The Next Step after 'Islam Kultural'?" in Al-Jāmi'ah: Journal of Islamic Studies 53/2 (2015), 284-286, https://doi.org/10.14421/ajis.2015.532.283-302.

13 Suzanne Brenner, "Reconstructing Self and Society: Javanese Muslim Women and 'the Veil'," American Ethnologist 23/4 (November 1996), 673-697, https://doi.org/10.1525/ae.1996.23.4.02a00010. 
culture. ${ }^{14}$ The encounter of a religion with a local culture has given birth to a mixed culture (syncretism) which is functional within the society. As a religion, Islam could develop into an adaptive culture since it is influenced by ideology and market interest. This is such an endless process within a society in which Islam has been continuously adapting to certain cultural processes. In other words, Islam is undergoing such kind of contextualization in such ultra-modern era which could change also its religious practices. Religion tends to be understood from its outer appearance; an image made by the people (aesthetic). Whereas ethical values as the substance of a religion which creates a blueprint of social practices do not give significant influence. ${ }^{15}$ It means that Islam which is more visible in the public sphere is due largely to the aesthetic factors rather than ethical values of religion.

Obviously, the growth of Islamic consciousness in Indonesia could be seen with the proliferation of Islamic institutions and publicly religious symbols. ${ }^{16}$ The phenomena of sharī'ah, halāl, hijrah among the celebrities and Ustādh celebs, for instance, have been seen as a trend, which does not only attract public attention about the new face of Indonesia celebrity but also the religious spirit of public figures, which became the spotlight, although substantially this change is still a debate.

Interestingly, this phenomenon is also well captured by the industry and world of entertainment. If in a few decades, the industry did not really consider the notion of halāl and sharīah as the focus of their product promotion, this change has created its own market. Halāl and sharīah are expressively and distinctively stated for Muslims as the biggest share of the products, not only for food but also fashion, cosmetics, and other health product industries This development, of course, cannot be separated from changes on the socio-political level, since reformation era when we could witness the abundant new Islamic institutions such as Islamic boarding schools, integrated Islamic schools, Islamic alms and donations, Islamic finance (bank, insurance, and pawnshop), Islamic hospitals and medication, Islamic political

14 James W. Dow, "The Evolution of Religion: Three Anthropological Approaches," Method \& Theory in the Study of Religion 18/1 (2006), 75-77.

15 Irwan Abdullah, Konstruksi dan Reproduksi Kebudayaan (Yogyakarta: Pustaka Pelajar, 2010), 113-114.

16 Hasan, "The Making of Public Islam," 236-237. 
parties, and even the latter from the moderate to the conservative ones. On the entertainment sides, the television, film, and music industries have also experienced significant variations, in which Islamic text and music narratives have their own segments in any range of age. However, this development does not necessarily shift or eliminate the level or class of society especially among Indonesian Muslims. On a high level of society, for instance, a new trend of people performing pilgrimage to Mecca either with standard price or with the most exclusive ones, many new fancy mosques built, more Muslims wearing hijāb (Muslim outfits) or attending religious sermons on TV or four or five-star hotels, etc, are some other Islamic consciousness which spotlights the phenomena.

In contrast to the New Order era in which people tend to hide their religious identity, since the beginning of the reformation era, Muslims are eager to demonstrate their religiosity. Hijrah, which is basically a ritual personal has become a collective action following the social movement of popular da' ${ }^{\top}$ wah which massively fills public space and social media. Recent research conducted by IDN found that hijrah has become a growing trend among Indonesian Muslim millennials (IDN Research Institute, 2020). Most of the respondents in the research agreed that some hijrah behaviors were mostly about their daily lifestyle changes. ${ }^{17}$ Similarly, another research by Farchan also mentions that the trend of hijrah, especially among urban millennial Muslims, puts a new color to Indonesian Islam. The interpretation of hijrah has undergone a transformative shift from the geographical realm as the concept of hijrah at the time of the Prophet Muhammad to the personal realm. The thinking construction of millennial generation thinking on hijrah, in general, is "changing attitudes, behavior, and lifestyles in accordance with Islamic values." 18

Obviously, democratization brought about media liberalization and Islamic media is not the exception. The most visible is the mushroomed of Islamic printing media such as books, novels, magazines, tabloids, and bulletins which for more than three decades

17 IDN Research Institute (2020), Indonesia Millennial Report 2020 https://cdn.idntimes.com/content-documents/Indonesia-millennial-report-2020byIDN-Research-Institute.pdf, accessed September 17, 2021.

18 Yusa' Farchan and Zulfa Rosharlianti, "The Trend of Hijrah: New Construction of Urban Millennial Muslim Identity in Indonesia," The Sociology of Islam 1/2 (June 2021), 1-24. 
had been subjected to government criticism and state restriction in the name of security, political stability, and economic development. Other phenomena of public Islam are the flourish of electronic media such as Islamic movies, Islamic soap operas (TV series), religious sermons on TVs, cyber da' $\mathrm{d}^{\mathrm{C}} \mathrm{ah}$, streaming radio, or online magazines, and also Islamic social media. All the above phenomena correspond with the demand of middle-class Muslims which also rising significantly.

The phenomena of public Islam which are blossoming and more visible nowadays are part of the democratization process in Indonesia. Along with the growth of Indonesian economics, the number of middle-class Muslims also rose significantly. ${ }^{19}$ The writer argues that the more visible Islam in the public spheres is part of the involvement of Indonesian Muslims in the democratization of the country. This phenomenon is significant for the future of Muslims' identity and also the future of a strong nation-state of Indonesia. Islamic identity is not manipulated by the state as during the New Order period, but also not forced by certain Islamic groups as happened lately. The rise of the involvement of Muslims in the public spheres secures private interests and also the building of Muslims' civil society.

The development of information technology plays a significant role in the pace of Islamic popular culture in Indonesia. The usage of modern tools such as TV, hand-phones, the internet, and social media in most Muslims' daily life has given significant influence to the way how Muslims live. Thanks to the availability and accessibility of the internet in Indonesian cities since the end of the Suharto regime, the Islamic popular culture has also increased significantly not only in the public spheres but also in the media. In the post-Suharto era, therefore, the cyber world is not only occupied by proponents of democratization but also by many radical Islamist groups. These various online activities -from democratization efforts to fundamentalist cyber wars- mirror the liberal attitude towards the internet in the post-Suharto era. The ease of accessibility of the internet in Indonesia becomes apparent in terms of the transition from an authoritarian to a more democratic political system. However, the widely spread of online and media literacy has eased ordinary Muslims to be more familiar with doctrinal concepts and religious reasoning which was previously mostly the domain of the religious scholars

19 Ariel Heryanto, Identity and Pleasure: The Politics of Indonesian Screen Culture (Singapore: NUS Press, 2014), 31-32. 
alone. ${ }^{20}$ Apparently, modernization gives significant changes to Muslims' religiosity. Hijab for example which was previously known as the outfits of outdated and low-level Muslims has been becoming more visible nowadays as a modern and middle-class daily life. Religious symbols which were previously well available in worship places such as mosques, nowadays are becoming more visible in public spheres. Hence, currently, Islam has become part of the popular culture in Indonesia.

\section{Commodification of Islam and "Aestheticization"}

In the Politics of Piety, Saba Mahmood articulates the concept of piety as a state of ''being close to God:' a manner of being and acting that suffused all of one's acts, both religious and worldly in character," ${ }^{21}$ the observance of Șalāt operated as more than a ritual obligation, but as a site of self-formation. Hence, "ritual (i.e., conventional, formal action) is understood as the space par excellence of making their desires act spontaneously in accord with pious Islamic conventions" 22

However, in the era of globalization, where social media then becomes an important part of contemporary life, religious commodification is unavoidable. Religious symbols, including piety, which previously were in the personal area, a secret relationship between man and his/her God, then shifts to a social or popular area which could be loaded with various interests. Hence, as noted by Mahmood, the religious practice, such as wearing a veil could be debatable whether it is kind of a false awareness, a pragmatic action, or because of religious patriarchy. ${ }^{23}$

The flourish of Islamic popular culture, the rise of middle-class Muslims, and the adoption of many symbols of modernity could be regarded as symbolic piety. The writer believes that re-Islamization

20 Armando Salvatore and Dale Eickelman, "Preface: Public Islam and the Common Good," in Public Islam and the Common Good, ed. A. Salvatore and Dale. F. Eickleman (Leiden: Brill, 2004), xi-xii.

21 Saba Mahmoud, Politics of Piety: The Islamic Revial and the Feminist Subject (Princeton \& Oxford: Princeton University Press, 2005), 122.

22 Mahmoud, "Rehearsed Spontaneity and the Conventionality of Ritual: Disciplines of 'Ṣalāt'," American Ethnologist 28, no. 4 (2001), 833. 
took place in Indonesia in terms that Muslims' religiosity rose significantly. The mixture of spirituality and modernity should not necessarily lead Islam to secularization as religions have more than merely survived well in many parts of the modern world. ${ }^{24}$ Berger even concludes that modernity does not necessarily bring about a decline of religion. ${ }^{25}$ Further, it is such a kind of new identity of moderate Muslims who could not only show their religiosity personally but also publicly. The writer, however, views that the re-Islamization of the country is such kind of shifting from old-fashioned to modern Islam.

The overwhelm of Islamic piety in Indonesia has given to the rise of Islamic popular culture and also popular piety culture. In the last ten years, public Islam has been represented by the abundance of religious symbols in any public sphere. Islamic fashion has been growing market all over the world, especially in Muslim majority regions such as Southeast Asia. ${ }^{26}$ Therefore, religious symbols in public are not only signs of Islamic popular culture and Muslims' consumerism, but also popular piety. Among the phenomena of popular piety are the growing usages of hijab among the middle class, performing 'umrah pilgrimage with celebrities, attending religious sermons on TV programs, etc.

Many middle-class Muslim women in some big cities in Indonesia are eager to join hijāb communities such as hijāber community, bijābers socialite (socialita), Kivitz, etc. On a certain occasion, the group held a religious gathering such as religious sermons, talk shows, luncheons, fashion shows, cooking classes, charity, etc. The Hijabers Community (HC) is one of the vendors of women's Muslim fashion that has many branches and organizes many events in some big cities in the country. As noted by Hoesterey in his article "Film Islami: Gender, Piety and Pop Culture in Post-Authoritarian Indonesia:"

24 Armando Salvatore, "Tradition and Modernity within Islamic Civilisation and the West," in Islam and Modernity: Key Issues and Debates, ed. Muhammad Khalid Masud, Armando Salvatore and Martin van Bruinessen (Edinburgh: Edinburgh University Press, 2009), 4-9.

25 Peter L. Berger, "Further Thoughts on Religion and Modernity," Society 49 (2012), 313, https://doi.org/10.1007/s12115-012-9551-y.

26 Annelies Moors, “Discover the Beauty of Modesty': Islamic Fashion Online," in Modest Fashion: Styling Bodies, Mediating Faith, ed. Reina Lewis (London \& New York: I. B. Tauris, 2013), 36, 10.5040/9780755694181.ch-001. 
With a relaxing of controls on freedom of expression in the post-1998 period, popular culture has been a fertile ground for aesthetic experimentation. Products that "breathe Islam" are increasingly popular among Muslim middle classes eager to explore new forms of religiosity through consumption and public piety (Fealy, 2008; Hasan, 2009; Hoesterey, 2008; Howell, 2008; Jones, 2007; Smith-Hefner, 2007). In addition to a surge in the popularity of religious commodities such as digital Qur'an, Islamic fashion, and cassette sermons, during the 1990 s and early 2000s, there was also remarkable growth in the Islamic publishing industry, especially in the market segment of Islamic selfhelp (Watson, 2005; Hoesterey, 2008; Fadjar et al., 2006) ${ }^{27}$

All the above phenomena are only a few examples of the flourish of popular piety. They share many things in common, i.e., the rise of middle-class Muslims, Muslim consumerism, the commodification of Islam, and others of the more observable of public Islam. In such circumstances, popular piety is becoming more obvious in society. Therefore, the writer tends to define Islamic popular piety as forms of various Islamic practices which are mostly driven by their circumstances rather than their belief.

Alexander Darius coins the term of commodification of religion as 'the supermarket of religion' which refers to commodities of religious symbols, the object of consumption which is readily available in economic life and the media landscape. As he further mentions, "it is a process of recontextualization of religious symbols, language, and ideas from the original religious context to media consumer culture." ${ }^{28}$ In terms of Indonesia, the mushroomed public Islam has created a giant market, consumerism, and commodification. The dynamic relationship between religiosity (public Islam) and commodification of Islam is a reciprocal phenomenon. On the one hand, the more public Islam reflects the need for more religious commodities, and the more widely consumed Islamic commodities the more widely spread of public Islam. Therefore, Indonesian Muslims nowadays require such religious practices which are performed in more fun, nice outfits, good

27 James B. Hoesterey and Marshall Clark, "Film Islami: Gender, Piety and Pop Culture in Post-Authoritarian Indonesia," Asian Studies Review 36 (June 2012), 207 226.

28 Alexander Darius Ornella, "Commodification of Religion," in Encyclopedia of Sciences and Religions, edited by Runehov A.L.C., Oviedo L. (Springer, Dordrecht, 2013), https://doi.org/10.1007/978-1-4020-8265-8_201034. 
branding, and good travel bureau, etc. Religious symbols and status such as hijāb among middle-class Muslims, attending religious sermons on TV stations, and 'umrah pilgrimage are becoming valuable commodities. This opportunity is being used by certain segments of the society to acquire more benefits, either media, trading, as well as travel bureaus.

Furthermore, all kind of lifestyle and reality are undeniably undergoing such kind of "aestheticization," and religions let alone Islam is not an exception. "Aestheticisation" is a critical concept to analyze the religious phenomena in contemporary society, which is marked by commodification and consumerism. A long time ago, Simmel has already indicated the rising of "aestheticization" of reality and the increasing importance of style. Further, he argued that in such a modern era, the essence of life is no longer important except as an art, the most significant of life is the image of live itself. ${ }^{29}$ The symptom of course may lead to the eclipse of the sacred, although the writer tends to say that it produces new experiences and religious emotions. Giuseppe and William even argue that aestheticization of religion not only underlines the importance of form and style, but also involves experiences and emotions. ${ }^{30}$

Modernization has been marked by the shifting of ethic to symbolic (consumptive) culture. Wearing clothes, for example, is not merely ethical needs but also a symbolic need that has to do with the kinds of clothes and the venue and atmosphere when the clothes are worn. Attending religious sermons on TV stations, for example, could not merely be considered as religious duties, but also as an aesthetic aspect of religiosity as people should wear proper and elegant clothes.

The glorification of Islam as described above in many ways then has an impact on the religious spirit and the search for the true truth of Islam. Symbolic religion is intertwined with modernization has caused many groups to lose their religious meaning. This is where the phenomenon of hijrah then thrives, especially among urban youth.

29 Georg Simmel, "The Problem of Style," Theory, Culture and Society 8 (1991), 6365.

30 Giuseppe Giordan and William H. Swatos, Jr. (eds.), Religion, Spirituality and Everyday Practice (Dordrecht: Springer, 2011). 
The term hijrah directs an individual in a process where he tries to become a more devout Muslim. ${ }^{31}$

The case of fancy-stylish hijāb and 'umrah pilgrimage could not only be seen as religious duties. It may be true that most people's first desires to wear hijāb or performing 'umrah pilgrimage are driven by their religion, although many others are not the case. The writers tend to underline here that many religious rituals have been filled up with religious celebrations which underline more on joy and pleasure. 'Umrah pilgrimage in Indonesia for example will not be as crowded as nowadays if there are no such offers to perform 'umrah with celebrities. Another similar phenomenon nowadays is the cumrah pilgrimage plus visiting Islamic historical countries such as Turkey, Egypt, Jordan, etc. Apparently, all the above phenomena are the capitalization of religion which shifted 'umrah as worship and also at the same time as religious refreshment.

Popular piety could also lead to objectification and privatization of religion. Some scholars of the Muslim modern world have noted that due to the widely spread of literacy and mass media, ordinary Muslims have become more familiar with religious basic concepts and doctrines which initially only belong to some religious scholars. The detachment of Muslims from their traditional and cultural belief and the selfcontained system was labeled by Dale Eickelman and James Piscatori as religious objectification. ${ }^{32}$ The widely available of various religious teachings on the internet have made Islam a more private domain. Although a Muslim could culturally belong to a certain religious group, in many cases one could freely decide for one's religious matters regardless of his/her religious affiliations.

Furthermore, as previously mentioned, another phenomenon to respond to this modernity are the Hijrah and Arabism movement. Taking a term from the Prophet Muhammad's Hijrah from Mecca to Medina, the new social movement which is currently developing among the millennial Muslim generation tries to find a new meaning

31 Yuyun Sunesti, Noorhaidi Hasan and Mubammad Najib Azca, "Young Salafiniqabi and Hijrah: Agency and Identity Negotiation," Indonesian Journal of Islam and Muslim Society 8/2 (2018), 173-197, https://doi.org/10.18326/ijims.v8i2.173198.

32 Dale F. Eickelman and James Piscatori, Muslim Politics (Princeton, NJ: Princeton University Press, 2004), 38-39. 
of Islam through hijrah. Interestingly, this movement is not only seen as a way to try to get back to the Islamic way of life by performing Islamic rituals and religious life, but also performing Arabic lifestyle, such as in fashion and utterances of communication in daily life. If the glorification of Islam after the New Order was marked by the use of hijab for the women, the hijrah movement is seen in the Islamic values juxtaposed with the Arabic lifestyle such as the use of Arabic kaftan, wide hijāb even with burqah or niqāb, and Muslim clothes (baju koko) with above the knee pants (cingkrang) for men. Somehow, it is followed by the changes in utterances in communication, by inserting or modifying with Arabic language such ukhtī, akhawāt, ikhwān, 'afw ${ }^{a n}$, fì amān Allāh, shafāka'llāh, jazākum Allāh khayr ${ }^{a n}$, bäraka'llāh, in shä'a'llāh, na'üdhu billāh, shukr ${ }^{a n}$, etc. which are getting popular in the last ten years.

It is undeniable that the presence of social media is one of the things that attract the millennial Muslim generation to do the hijrah movement. It is even seen as a modern way of Islamic preaching which helps the millennial Muslims understand religion better and bring them closer to their faith. Social media spreads the circulation of information about the study of Islam quickly and widely, including the hijrah movement. Therefore, hijrah for the millennial Muslim generation can be considered as a medium in creating a religious identity that is framed in the construction of the $\mathrm{da}^{\mathrm{c}} \mathrm{w}$ ah movements

The above phenomena are actually part of the globalization and democratization process that have been developing in society. As mentioned above, after the New Order, the reformation era which are later supported by significant developments in the digital world does not only foster a stronger religious milieu such as the massive of hijāb and dakwah movement or the hijrah among the youth, but also the religious commodification by creating a very dynamic and various trends of religious piety which is so-called popular piety.

\section{Secularization or Moderating Islam}

Many people may assume that globalization and modernization would marginalize religions and push religious values near to vanish. In the same vein, many scholars argue that religions could not mingle with a globalized world. The writer certainly agrees with Berger arguing that although modernization may have some secularization effects, some counter-secularization may arise in the form of 
spiritualism or individual religious consciousness. ${ }^{33}$ Turner even asserts that globalization invokes the rise of new forms of spirituality, especially middle-class people who have been influenced by western consumer values. ${ }^{34}$ Kitiarsa also proposes that the turn of religion into marketable goods in Asia is part of secularization. ${ }^{35}$ There are many aspects of popular Islam which seems could justify this assumption such as that the commodification of Islam would desacralize the religious aspects of Islam, that popular piety could lead to religious formality or symbolic piety, that popular piety could lead Muslims to be more permissive, etc. The writer contends, however, that globalization and modernization do not necessarily require secularization, at least, in the case of Indonesia.

The onward development of modernization does not necessarily entail secularization. Contemporary modern Islam in many parts of the world has proved that Islam could survive and attested.$^{36}$ It may be true that commodification of Islam could desacralize the religious aspects of Islam. The growth of dahwahtainment on TV and the internet has been criticized as artificial preaching, because it focuses on the packages of entertainment rather than the content of da'wah itself. But, in my view, modernization could even add to the religious passions of Muslims. In addition, their choice of religious style is in accordance with their rational choice rather than previously which was more on emotional or cultural choice. The rational choice on their religiosity in many senses necessitates them to learn more about their religion. In choosing how to dress for their daily life, how to perform 'umrah pilgrimage and religious sermons, and how to change their lifestyle

33 Peter L. Berger, "The Desecularization of the World: A Global Overview," in The Desecularization of the World: Resurgent Religion and World Politics, ed. Peter L. Berger (Washington: Ethic and Public Policy Center, 1999), 1-5.

34 Bryan S. Turner, "Religious Diversity and the Liberal Consensus," in Religious Diversity and Civil Society: A Comparative Analysis, ed. Bryan S. Turner (Oxford: The Bardwell Press, 2008), 65-66.

35 Pattana Kitiarsa, "Introduction: Asia's Commodified Sacred Canopies," in Religious Commodifications in Asia: Marketing Goods, ed. Pattana Kitiarsa (London: Routledge, 2008), 3.

36 Berger, The Many Altars of Modernity: Toward a Paradigm for Religion in a Pluralist Age (Boston \& Berlin: De Gruyter, 2014), 68-69. 
Muslims are engaged in religious creativity. ${ }^{37}$ The mixture of spirituality and modernity should not necessarily lead Islam to secularization as religions have more than merely survived well in many parts of the modern world.$^{38}$ Rather, it is such a kind of new identity of -let's saymoderate Muslims who could not only show their religiosity personally but also publicly. In the view of the writer, however, the reIslamization of the country is such a kind of shifting from old-fashioned to modern Islam.

In this sense, a research by Fatimah Husein sees a change in the theology of piety from the personal to the social realm. Taking some phenomena of șadaqab (charity) and reciting Qurāan, One Day One Juz' (ODOJ) she examines "how riy $\bar{a}$, an established concept in Islamic theology that refers to showing off one's piety, has gained new relevance in the context of contemporary uses of social media for religious purposes." 39 According to Campbell, since "digital religion," being present on a variety of online media ranging from websites to mobile apps, "does not simply refer to religion as it is performed and articulated online, but points to how digital media and spaces are shaping and being shaped by religious practice." ${ }^{40}$

On the account that popular piety could lead to religious formality or symbolic piety, the writer tends to maintain that popular piety is another 'approach' of formal piety. The presence of Muslims in the religious sermons, wearing hijāb, and 'umrah pilgrimage would not happen unless they are eager to do so. The most obvious is the slogan of a hijāb vendor sharci \& stylish which does not disobey to the most religious aspects of religious practices, shar'ī. Similarly, the other forms of popular piety also will not violate the religious values of Islam.

It might be true that popular piety could lead Muslims to be more permissive, in terms that Islamic values are less sacred. The most

37 John R. Bowen, A New Anthropology of Islam (Cambridge: Cambridge University Press, 2012), 42.

Ariel Heryanto, Identity and Pleasure, 31.

39 Fatimah Husein and Martin Slama, "Online Piety and its Discontent: Revisiting Islamic Anxieties on Indonesian Social Media," Indonesia and the Malay World 46/134 (2018), 80, https://doi.org/10.1080/13639811.2018.1415056.

40 Heidi A. Campbell, "Introduction: The Rise of the Study in Digital Religion," in Digital Religion: Understanding Religious Practice in New Media Worlds, ed. Heidi. A. Campbell (London: Routledge, 2013), 1. 
current obvious phenomenon is the phenomenon of jilbāb. The enthusiasm of women Muslims to wear $j i l b \bar{a} b^{41}$ is obvious in many different levels of society so that emerged the term jilbāb. This term satirizes many teenage urban women Muslims wearing a scarf but does not really cover their chest. It will not be a problem of course if they do not wear scarfs at all. The jilbāb phenomenon may be the most apparent for the permissiveness of Muslims which could lead to be secular or liberal views.

The phenomena of public Islam which is blossoming and more visible nowadays are part of the democratization process in Indonesia. Along with the growth of Indonesian economics, the number of middle-class Muslims also rose significantly. The writer argues that the more visible Islam in the public spheres is part of the involvement of Indonesian Muslims in the democratization of the country. The more modern a Muslim, the more he would learn that Muslims require modern ideas such as equality and democracy and no longer consider them as merely Western values. ${ }^{42}$ This phenomenon is significant for the future of Muslims' identity and also the future of a strong nationstate of Indonesia. The rise of the involvement of Muslims in the public spheres secures private interests and also the building of Muslims' civil society.

\section{Reproduction of Islamic values}

The flourish of popular piety culture in a broader context is such as the process of social reproduction of Islamic values. As many Muslims believe, the writer does consider that Islamic values are ageless, eternal, and cross the boundaries of space and time. Islam which has been survived for centuries proved that it accommodates local and modern values. As Kitiarsa argues, popular piety culture is a "complex historical and cultural construction" that does not necessarily lead to religious disorder or yield new religious forms that contradict with the

41 The term jilbāb which is derived from Q 33:59 means a scarf or veil that cover women Muslims' head and chest. In many cases, jilbāb and hijāb are used interchangeably, but in Indonesian context, jilbāb is a scarf and a part of hijāb. From the perspective of sharīah, therefore, many jilbāb do not qualify the concept of hijāb.

42 Hefner, "Public Islam and the Problem of Democratization," Sociology of Religion 62/4 (Winter 2001), 498. 
existing religious belief and practices. ${ }^{43}$ The presence of Islamic popular culture nowadays could not be considered as fleeting, worldly, or even not Islamic. As Talal Asad portrays Islam as a drama of religiosity, he asserts that "Islam does not belong to a "fixed stage of an Islamic theatre." Along with the development of the world, Islam also develops in its ways to adjust to any socio-cultural contexts. ${ }^{44}$ Therefore, popular piety cultures which grow in many Muslim worlds are part of the reproduction of Islamic values.

The first point is the shifting of Islamic values from traditional to modern ones. As the writer has indicated in the previous paragraph, Indonesian Muslims during the reformation era have made a substantial leap from traditional to "fashionable" Islam. Previously, Muslims are anxious and afraid to express their identity as Muslims such as to convey Islamic greetings to other Muslim counterparts or in certain official forums, to wear religious attire such as hijāb in public space, etc. During the Suharto era, hijāb for example had been seen mostly as the attire of rural area people. ${ }^{45}$ Nowadays, Islam is not only present in the public sphere but even is becoming an elite culture. The most obvious is hijāb which is not only worn by middle-class Muslims as their religious duties but even by many celebrities as a popular lifestyle. Islam has been seen by Indonesian Muslims as their new identity.

The second point is that Islam becomes an urban and fashionable lifestyle. Islamic sermons (Ind. Pengajian) for example are no longer as religious duties but also as formalities. In the previous era, religious sermons were purely religious duties that were held in mosques or private houses. As Islam nowadays has been as a public realm, religious sermons are held at fancy urban mosques or four-five star hotels. This trend brings about a new enthusiasm and dynamism for Muslim urbanites to exhibit Islam in their daily life, hence new demands for contextualized values of Islam. ${ }^{46}$ The emergence of some

43 Kitiarsa, "Introduction: Asia's Commodified Sacred Canopies," 3.

44 Talal Asad, "The Idea of an Anthropology of Islam", in Occasional Papers (Washington DC: Center for Contemporary Arab Studies, Georgetown University, 1986), 11.

45 Brenner, "Reconstructing Self and Society."

46 Akh Muzakki, "Islam as a Symbolic Commodity: Transmitting and Consuming Islam through Public Sermons in Indonesia," in Religious Commodifications in Asia: Marketing Goods., ed. Pattana Kitiarsa (London: Routledge, 2008). 
modern urban Sufism ${ }^{47}$ in some big cities as Jakarta explains how Islam is becoming the lifestyle of urban middle-class Muslims. The sermons on TV stations are also a good example of how Muslims considered religious sermons as part of their lifestyle. Apparently, this shifting is such a transformation of Islam from traditional and rural religion to be urban and modern Islam.

Finally, the notion of $u s t \bar{a} d h$ and ' $u l a m \bar{a}$ ' also undergo such kinds of social and cultural negotiations. Initially, the terms ustädh and ' $u l a m \bar{a}$ ' in Indonesia refer to a person having broad and deep religious values after finishing his study in religious schools. The status of $u s t \bar{a} d h$ or ' $u l a m \bar{a}$ ' itself is more ascribed by the society rather than achieved; it is quite sacred status within society. Nowadays, the perception of society toward ustādh is slightly changing. The more presence Islam in the public sphere in the form of popular culture entail many ustādhs appear on TV programs and other public spheres. This phenomenon brought about major differences between ustädh and 'ulama' in Indonesian context. While the term 'ulama' ' does not change much in society, recently the status of $u s t \bar{a} d h$ is slightly below the status of ' ulama's. This phenomenon happened due to the emergence of a new term, i.e., ustādh celeb, which refers to young $u s t \bar{a} d h s$ who are famous among the youths and middle-class and frequently appear on TV programs. Some notable ustādh celebs are Ust. Yusuf Mansur, Ust. Solmed (Sholeh Mahmud Nasution), Ust. Nur Maulana, and the late Ust. Uje (Ustadh Jefri Al-Buchori). The presence of some ustādh celebs attracts many young and middle-class Muslims to learn Islam as these $u s t \bar{a} d h$ could interpret or reproduce Islamic values in accordance with the need of the middle-class urbanites.

\section{Conclusion}

Amidst the surge of global Islamism and the contestation of religiosity in Indonesia from the ultra-conservative, moderate, to the liberal Islam ones, Indonesian Muslims demonstrate their visibility in the public spheres. The rise phenomena of Islamic popular piety are among the ongoing process of accommodation of Indonesian Muslims toward globalization and also modern values. Therefore, the writer believes that popular piety culture would take part significantly to

Some notable urban Sufism in Jakarta are Manajemen Qalbu of Abdullah Gymnastiar, Majlis Dzikir of Arifin Ilham, Emotional-Spiritual Quotient of Ary Ginanjar, and Sentuhan Qalbu of Firdaus Djamari. 
modernize Indonesian Islam. Although popular piety could be simply understood as swallowing of Islamic belief, the writer tends to argue that it could be seen as the phenomenon of aestheticization and privatization of religion and also part of the reproduction of Islamic values. Eventually, popular piety is such a process of moderaterational Muslims' contestation and negotiation in the public sphere.

While conservative Muslims or Islamists always refer to scripturalist Islam, Islamic popular culture refers to Islam of the mass' and the populace's interpretation of Islamic values. Therefore, the notion of Islamic popular culture is inclusive, adopts much of local values, and is popular among urban and middle-class Muslims. In this context, Weintraub asserts that Muslim popular culture is such a mixture of global Islamic resurgence, Western consumer culture, and also local cultures. ${ }^{48}$ In the meantime, contestations of many different poles of religious beliefs also take part in adjusting religious life in the country. Islamic da'wah and teachings which are broadly available in many forms give a lot of choices for Muslims to choose which is suitable for their levels of religious beliefs. All the dynamic socio-cultural interaction undoubtedly will not bring about Indonesian Islam into literalist or scripturalist Muslim, but moderate one instead. In general, Islamic popular culture could be seen as part of the post-Islamism process in Indonesian Islam.

The phenomena of Islamic popular culture could be seen as the emergence of Indonesian middle-class Muslims. Along with modernization, the wake of Indonesian Islamic religiosity is represented nowadays by Muslim urbanites. It was them who may dominate the contestation of religious narratives. Although there are many variants of Islam among the urbanite Muslims, some modernization values such as rationalism when it meets with religiosity would generate and reproduce new modern values in Islam.

\section{DISCLOSURE STATEMENT}

No potential conflict of interest was reported by the author.

48 Andrew N. Weintraub, "Introduction: The Study of Islam and Popular Culture in Indonesia and Malaysia," in Islam and Popular Culture in Indonesia and Malaysia, ed. Andrew N. Weintraub (London: Routledge, 2011), 3. 


\section{FUNDING}

The author received no specific grant from any funding agency in the public, commercial or not-for-profit sectors.

\section{BIBLIOGRAPHY}

Abdullah, Irwan. Konstruksi dan Reproduksi Kebudayaan. Yogyakarta: Pustaka Pelajar, 2010.

Asad, Talal. "The Idea of an Anthropology of Islam." In Occasional Papers. Washington DC: Center for Contemporary Arab Studies, Georgetown University, 1986.

Azra, Azyumardi. "Political Islam in post-Soeharto Indonesia." In Islamic Perspectives on the New Millennium, edited by Virginia Hooker and Amin Saikal, 133-149. Singapore: ISEAS, 2004. https://doi.org/10.1355/9789812305367-010.

Berger, Peter L. "Further Thoughts on Religion and Modernity." Society 49 (2012): 313316. https://doi.org/10.1007/s12115-012-9551-y.

- "The Desecularization of the World: A Global Overview." In The Desecularization of the World: Resurgent Religion and World Politics, edited by Peter L. Berger, 1-18. Washington: Ethic and Public Policy Center, 1999.

- The Many Altars of Modernity: Toward a Paradigm for Religion in a Pluralist Age. Boston \& Berlin: De Gruyter, 2014.

Bowen, John R. A New Anthropology of Islam. Cambridge: Cambridge University Press, 2012.

Brenner, Suzanne. "Reconstructing Self and Society: Javanese Muslim Women and 'the Veil'." American Ethnologist 23, no. 4 (1996), 673-697. https://doi.org/10.1525/ae.1996.23.4.02a00010

Campbell, Heidi. A. "Introduction: The Rise of the Study in Digital Religion." In Digital Religion: Understanding Religious Practice in New Media Worlds, edited by Heidi A. Campbell, 1-22. London: Routledge, 2013. https://doi.org/10.4324/9780203084861.

Eickelman, Dale F. and Jon W. Anderson. "Redefining Muslim Publics." In New Media in the Muslim World: the Emerging Public Sphere, edited byDale F. Eickelman and Jon W. Anderson, 1-18. Bloomington: Indiana University Press, 2003.

Eisenstadt, S. N. "Multiple Modernities." Daedalus 129, no. 1, (2000): 1-29. https://doi.org/10.1177/03058298000290031201. 
Farchan, Yusa' and Zulfa Rosharlianti. "The Trend of Hijrah: New Construction of Urban Millennial Muslim Identity in Indonesia." The Sociology of Islam 1/2 (2021): 1-24.

Fealy, Greg. "Consuming Islam: Commodified Religion and Aspirational Pietism in Contemporary Indonesia." in Expressing Islam: Religious Life and Politics in Indonesia edited by Greg Fealy and Sally White, 15-39. Singapore: ISEAS, 2008. https://doi.org/10.1355/9789812308528-006.

Hasan, Noorhaidi. "The Making of Public Islam: Piety, Agency, and Commodification on the Landscape of the Indonesian Public Sphere." Contemporary Islam 3, no. 3 (2009): 229-250. https://doi.org/10.1007/s11562-009-0096-9.

Hefner, Robert W. "Public Islam and the Problem of Democratization." Sociology of Religion 62, no. 4 (2001): 491-514. https://doi.org/10.2307/3712438.

- Civil Islam, Muslims and democratization in Indonesia. Princeton: Princeton University Press, 2000.

Heryanto, Ariel. Identity and Pleasure: The Politics of Indonesian Screen Culture. Singapore: NUS Press, 2014. https://doi.org/10.2307/j.ctv1qv1rz.

Hoesterey, James B. and Marshall Clark. "Film Islami: Gender, Piety and Pop Culture in Post-Authoritarian Indonesia." Asian Studies Review 36 (2012): 207-226. https://doi.org/10.1080/10357823.2012.685925.

Howell, Julia Day. "Sufism and the Indonesian Islamic Revival." The Journal of Asian Studies 60, no. 3 (2001): 701-729. https://doi.org/10.2307/2700107.

Husein, Fatimah and Martin Slama. "Online Piety and its Discontent: Revisiting Islamic Anxieties on Indonesian Social Media." Indonesia and the Malay World 46, no. 134 (2018): 80-93. https://doi.org/10.1080/13639811.2018.1415056.

IDN Research Institute. (2020). Indonesia Millennial Report 2020. https://cdn.idntimes.com/content-documents/Indonesia-millennial-report2020-byIDN-Research-Institute.pdf

Kitiarsa, Pattana. "Introduction: Asia's Commodified Sacred Canopies." In Religious Commodifications in Asia: Marketing Goods, edited by Pattana Kitiarsa, 1-12. London: Routledge, 2008. https://doi.org/10.4324/9780203937877

Lapidus, Ira. M. "Islamic Revival and Modernity: The Contemporary Movements and the Historical Paradigms." Journal of the Economic and Social History of the Orient 40, no. 4 (1997): 444-460. https://doi.org/10.1163/1568520972601486.

Lukens-Bull, R. A Peaceful Jihad: Negotiating Identity and Modernity in Muslim Java. New York: Palgrave Macmillan, 2005. https://doi.org/10.1057/9781403980298.

Mahmood, Saba. Politics of Piety. Princeton: Princeton University Press, 2005.

- "Rehearsed Spontaneity and the Conventionality of Ritual: Disciplines of "Ṣalāt," American Ethnologist 28, no. 4 (2001), 827-853. https://doi.org/10.1525/ae.2001.28.4.827. 
Moors, Annelies. "Discover the Beauty of Modesty': Islamic Fashion Online.” In Modest Fashion: Styling Bodies, Mediating Faith and Modernity, edited by Reina Lewis, 17-40. London \& New York: I. B. Tauris, 2013. 10.5040/9780755694181.ch-001.

Muzakki, Akh. "Islam as a Symbolic Commodity: Transmitting and Consuming Islam through Public Sermons in Indonesia." In Religious Commodifications in Asia: Marketing Goods, edited by Pattana Kitiarsa, 219-233. London: Routledge, 2008.

Noor, Farish A. "Popular Religiosity in Indonesia Today: The Next Step after 'Islam Kultural'?" Al-Jāmi‘ah: Journal of Islamic Studies 53, no. 2 (2015): 284-286. doi: 10.14421/ajis.2015.532.283-302.

Ornella, Alexander Darius. "Commodification of Religion." In Encyclopedia of Sciences and Religions, edited by Runehov A.L.C., Oviedo L. Springer, Dordrecht, 2013. https://doi.org/10.1007/978-1-4020-8265-8_201034.

Salim, Arskal. "Muslim Politics in Indonesia's Democratisation: The Religious Majority and the Rights of Minorities in the Post-New Order." In Indonesia: Democracy and the Promise of Good Governance, edited by R. H. McLeod \& A. MacIntyre, 115-137. Singapore: ISEAS, 2007. https://doi.org/10.1355/9789812304674-011.

Salvatore, Armando and Dale Eickelman. "Preface: Public Islam and the Common Good." In Public Islam and the Common Good, edited by A. Salvatore and D. F. Eickleman, xi-xxv. Leiden: 2004. https://doi.org/10.1163/9789047402824.

Salvatore, Armando. "Tradition and Modernity within Islamic Civilisation and the West." In Islam and Modernity: Key Issues and Debates, edited by Muhammad Khalid Masud, Armando Salvatore and Martin van Bruinessen, 3-35. Edinburgh: Edinburgh University Press, 2009.

Sofjan, Dicky, ed. Religion and Television: Ethics Surrounding Dakwabtainment. Geneve: Globethics, 2013.

. "Gender Construction in Dakwahtainment: A Case Study of Hati ke Hati Bersama Mamah Dedeh." Al-Jāmicab: Journal of Islamic Studies 50/1 (2012): 57-74. https://doi.org/10.14421/ajis.2012.501.57-74.

Sunesti, Yuyun, Noorhaidi Hasan, and Muhammad Najib Azca. 'Young Salafi-Niqabi and Hijrah: Agency and Identity Negotiation." Indonesian Journal of Islam and Muslim Society $\quad 8, \quad$ no. 2 (2018): 173-198. https://doi.org/10.18326/ijims.v8i2.173-198.

Turner, Bryan S., ed. Religious Diversity and Civil Society: A Comparative Analysis. Oxford: The Bardwell Press, 2008.

Weintraub, Andrew N., "Introduction: The Study of Islam and Popular Culture in Indonesia and Malaysia." In Islam and Popular Culture in Indonesia and 
Malaysia, edited by Andrew N. Weintraub, 1-17. London: Routledge, 2011. https://doi.org/10.4324/9780203829004. 